\section{Zika virus infection and congenital anomalies in the Americas: opportunities for regional action}

\author{
Mariela Larrandaburu, ${ }^{1}$ \\ Fernanda Sales Luiz Vianna, ${ }^{1}$ \\ André Anjos da Silva, ${ }^{1}$ Luis Nacul, ${ }^{2}$ \\ Maria Teresa Vieira Sanseverino, ${ }^{1}$ \\ and Lavínia Schuler-Faccini ${ }^{1}$
}

Suggested citation Larrandaburu M, Vianna FSL, Anjos-daSilva A, Nacul L, Sanseverino MTV, and Schuler-Faccini L. Zika virus infection and congenital anomalies in the Americas: opportunities for regional action. Rev Panam Salud Publica. 2017;41:e174. doi: 10.26633/RPSP.2017.174.

\begin{abstract}
The Zika virus (ZIKV) was identified in 1947 in the Zika forest in Uganda, but recently it has emerged as a public health threat. The first evidence of human infection occurred in 1952, but only in April 2007 was the first outbreak in humans recognized. In the Americas, a ZIKV outbreak began in Brazil in 2015, and from the second half of 2015 onward, a substantial number of newborns with severe microcephaly began to be reported to health authorities. In February 2016, the World Health Organization (WHO) declared that the clusters of microcephaly cases in areas affected by ZIKV constituted a Public Health Emergency of International Concern. Seldom has there been such a resultingly vast production of scientific literature in record time. In this report we discuss the impact of ZIKV infection during pregnancy, the diagnosis and surveillance of microcephaly, the recognition of a clinical phenotype of ZIKV congenital infection, and opportunities for public health action.
\end{abstract}

\footnotetext{
Postgraduate Program in Genetics and Molecular Biology, Universidade Federal do Rio Grande do Sul, Porto Alegre, Rio Grande do Sul, Brazil. Send correspondence to Lavinia SchulerFaccini, at 1schuler@hcpa.edu.br

2 London School of Hygiene and Tropical Medicine School, London, United Kingdom.
}

We consider this to be a unique opportunity for countries in the Region of the Americas to develop, strengthen, and improve surveillance systems for congenital anomalies and teratogen information services. Creating health needs assessment tools for low- and middle-income countries may help them to develop effective policies to ensure primary, secondary, and tertiary prevention measures for congenital anomalies. Such initiatives will be useful for ZIKV congenital syndrome control and also for having a much wider impact on a significant proportion of preventable and manageable congenital conditions.

Keywords Zika virus; microcephaly; epidemiological surveillance; Americas.

On 1 February 2016, the World Health Organization (WHO) declared that the clusters of microcephaly cases and other neurological disorders such as Guillain-Barré syndrome in some areas affected by Zika virus (ZIKV) constituted a Public Health Emergency of International Concern (PHEIC) (1). "The increased prevalence of microcephaly at birth is particularly alarming, because it is a painful burden on the families and communities," pointed out WHO Director-General Margaret Chan (2).

The Zika virus was identified in the 1940s in the Zika forest in Uganda in monkeys. The first evidence of infection in humans occurred in 1952. Some five decades later, the international community recognized that the first ZIKV outbreak in humans had occurred in April 2007 in Yap, one of the states of the Federal States of Micronesia, in the Pacific Ocean. At that time, the transmission was reported in 10 other Pacific island countries and areas (3). In the Americas, the virus entered through Brazil, probably in 2013 (3). By November 2016, 48 countries in the Americas had reported autochthonous cases (4), with the Aedes aegypti mosquito being the most significant vector (5).

In this report we discuss the impact of ZIKV infection in pregnancy, the diagnosis and surveillance of microcephaly, the recognition of a clinical phenotype of ZIKV congenital infection, and opportunities for public health action in countries in the Americas.

\section{HOW THE MICROCEPHALY OUTBREAK WAS DETECTED}

In early 2015, Brazil's Ministry of Health began to receive reports of cases of an eruptive condition of unknown cause, especially in states in the Northeast 
region (6), and by April 2015, ZIKV was detected in those patients (7). The clinical manifestations were mild, with many regressing spontaneously without any clinical intervention. From the second half of 2015 onward, cases of newborns with microcephaly (8) and eye abnormalities began to be reported (9).

Microcephaly is defined as a smaller than expected occipital-frontal head circumference (OFHC) for gender and gestational age. Since the growth of the cranium depends on the forces of the expanding brain, microcephaly is a measure of brain development. Measurement of newborn OFHC is a screening tool for detecting microcephaly independently from its cause. This condition is a clinical finding that can manifest in isolation or as part of different syndromes caused by genetics (genetic or chromosomal) or environmental factors.

In Brazil, between October 2015 and November 2016, 10276 cases of microcephaly were reported in accordance with the definition of the Health Ministry's surveillance protocol, which includes newborns and fetal losses. Of these, 3113 (30.3\%) of the cases remain under investigation at the time of this manuscript submission, 2189 cases (21.3\%) have been confirmed for microcephaly and/or central nervous system abnormalities suggestive of congenital infection, and 4974 cases were ruled out (10). In 2010, the Brazilian Live Birth Information System (SINASC) reported a prevalence of microcephaly in Brazilian newborns of 5.7 cases per 100000 live births (11). However, according to the Latin American Network of Congenital Malformations (ECLAMC), in Brazil there had been no reliable data on microcephaly before the Brazilian epidemic, even for those cases considered to be severe. Thus, at this time, the focus on this anomaly could lead to overreporting and misdiagnosis (12).

\section{CLINICAL PHENOTYPE AND THE RECOGNITION OF A NEW TERATOGENIC SYNDROME}

In Brazil, by one year after the ZIKV outbreak, more the 1500 cases of congenital microcephaly associated with maternal ZIKV infection had been described. The phenotype can be defined as an "embryo-fetal brain disruption sequence by the Zika virus" (EFDS-ZIKV). The phenotype involves severe cerebral lesions and a dysmorphic spectrum ranging from babies with mild/ moderate to severe microcephaly secondary to the brain disruption sequence, and often neurological signs of cortical damage such as hypertonia and arthrogryposis (13).

Table 1 summarizes the clinical findings (from neuroimaging and pathology) from the reported cases, most of which were autochthonous infections in Brazil. Two reports are directed towards the neuroimaging findings, and two others have relevant information about the fetal postmortem findings. It is now acknowledged that microcephaly is perhaps only part of the spectrum of congenital ZIKV infection, where some babies born without microcephaly have manifested neurological abnormalities only after the neonatal period (14).

\section{EPIDEMIOLOGICAL SITUATION OF ZIKA VIRUS AND SURVEILLANCE SYSTEMS FOR CONGENITAL ANOMALIES IN THE AMERICAS}

By November 2016, 48 countries/territories of the Americas had already confirmed cases of autochthonous ZIKV infection (increasing from 34 at the beginning of 2016). Besides Brazil (with more than 1500 cases), 20 countries had reported congenital syndromes associated with Zika virus: Colombia (58 cases); the United States of America (31); Guatemala (15); French Guiana and Martinique (14 each); the Dominican Republic (10); Panama (5); El Salvador and Puerto Rico (4 each); Plurinational State of Bolivia (3); Costa Rica, Honduras, Paraguay, and Suriname (2 each); and Argentina, Canada, Grenada, Guadeloupe, Haiti, and Trinidad and Tobago (1 each).

Thirteen countries/territories in the Region of the Americas (Brazil, Colombia, the Dominican Republic, El Salvador, French Guiana, Guadeloupe, Guatemala, Honduras, Jamaica, Martinique, Puerto Rico, Suriname, and Venezuela) have reported an excess of Guillain-Barré syndrome (GBS), with at least one case involving laboratorial confirmation of ZIKV $(5,14)$. Before 2015 , only 11 countries in the Americas had a surveillance system for congenital anomalies (SSCA): 5 in the Andean Region and Southern Cone (Argentina, Brazil, Chile, Colombia, Uruguay), 3 in the Caribbean and Central America (Costa Rica, Cuba, Puerto Rico), and 3 in North America (Canada, Mexico, United States). After the ZIKV outbreak in 2015, 8 countries started an SSCA program: 3 in the Andean Region (Ecuador, Paraguay, Peru) and 5 in the Caribbean and Central America (Dominica, the Dominican Republic, El Salvador, Nicaragua, Panama).

Other modes of transmission, such as sex, blood transfusions, and organ transplants, may contribute (albeit on a much smaller scale) to the spread of the disease (15).

Table 2 summarizes the main characteristics of congenital anomaly surveillance systems, along with the baseline for microcephaly prevalence at birth in Latin America before the ZIKV epidemic in 2015. Brazil, for example, has had the nationwide Live Birth Information System (SINASC). The certificate of live birth is compulsory, and the presence of congenital anomalies must be registered on it. It was precisely this system that, despite its many weaknesses (mainly underreporting), enabled the confirmation of the microcephaly outbreak in Brazil, which had been initially notified by pediatric neurologists. Costa Rica and Uruguay have had population-based systems for the surveillance of congenital anomalies, while other countries have had hospital-based systems, one of which includes data from various South American countries. 
TABLE 1. Clinical phenotype of Zika virus embryopathy in confirmed and suspected cases

\begin{tabular}{|c|c|c|c|c|c|c|c|c|c|c|c|}
\hline \multirow{2}{*}{ Clinical, neuroimaging, and pathological findings } & \multicolumn{11}{|c|}{$\begin{array}{l}\text { Published studies and case reports } \\
\text { (no. of cases) }\end{array}$} \\
\hline & $\begin{array}{c}\text { A } \\
(35)\end{array}$ & $\begin{array}{c}\mathrm{B} \\
(3)\end{array}$ & $\begin{array}{c}C \\
(4)\end{array}$ & $\begin{array}{c}D \\
(1)\end{array}$ & $\begin{array}{c}E \\
(1)\end{array}$ & $\begin{array}{c}F \\
(2)\end{array}$ & $\begin{array}{c}G \\
(12)\end{array}$ & $\begin{array}{c}\mathrm{H} \\
(4)\end{array}$ & $\begin{array}{c}1 \\
(13)\end{array}$ & $\underset{(23)}{J}$ & $\begin{array}{c}\mathrm{K} \\
(13)\end{array}$ \\
\hline Microcephaly & $\bar{X}$ & $\mathrm{X}$ & $\mathrm{X}$ & $\mathrm{X}$ & $\mathrm{X}$ & $\mathrm{x}$ & $\bar{x}$ & $\mathrm{X}$ & $\bar{x}$ & $\bar{X}$ & $N D^{\mathrm{a}}$ \\
\hline Corpus callosal anomaly & $x$ & ND & $\mathrm{X}$ & ND & $\mathrm{X}$ & $\mathrm{x}$ & $x$ & ND & $x$ & $x$ & $\mathrm{x}$ \\
\hline Vermian anomaly & $x$ & ND & $\mathrm{x}$ & ND & ND & $x$ & ND & ND & ND & ND & ND \\
\hline Variable ventricular dilatation & $x$ & ND & $\mathrm{X}$ & $\mathrm{X}$ & $\mathrm{X}$ & $\mathrm{X}$ & $x$ & ND & $x$ & $\mathrm{x}$ & $\mathrm{X}$ \\
\hline Cerebral calcifications & $x$ & $\mathrm{X}$ & $\mathrm{x}$ & $x$ & $\mathrm{X}$ & $\mathrm{X}$ & $x$ & $\mathrm{X}$ & $x$ & $x$ & $\mathrm{X}$ \\
\hline Brain atrophy & $x$ & ND & ND & ND & $\mathrm{X}$ & $\mathrm{X}$ & ND & ND & ND & $\mathrm{x}$ & ND \\
\hline Enlarged cisterna magna & $x$ & ND & ND & ND & ND & $\mathrm{X}$ & ND & ND & ND & $\mathrm{x}$ & $\mathrm{X}$ \\
\hline Hypoplasia of the brain stem and spinal cord & ND & ND & ND & $\mathrm{x}$ & ND & ND & ND & ND & ND & $x$ & $x$ \\
\hline Neuronal migration disorders & $x$ & ND & $\mathrm{x}$ & $\mathrm{x}$ & $\mathrm{X}$ & $\mathrm{x}$ & $x$ & ND & $x$ & $x$ & ND \\
\hline Variable gliosis & ND & ND & ND & ND & $\mathrm{x}$ & ND & ND & $\mathrm{x}$ & ND & ND & ND \\
\hline Microphthalmia & $x$ & ND & ND & ND & ND & ND & ND & ND & $N A^{b}$ & NA & NA \\
\hline $\begin{array}{l}\text { Alterations in the macula and gross macular pigment } \\
\text { mottling }\end{array}$ & ND & $x$ & ND & ND & ND & ND & ND & ND & NA & NA & ND \\
\hline Fovea reflex loss & ND & $x$ & ND & ND & NA & ND & ND & ND & NA & NA & ND \\
\hline $\begin{array}{l}\text { Hypertonia, spasticity, seizures, hyperreflexia, } \\
\text { irritability, tremors }\end{array}$ & $\mathrm{x}$ & ND & ND & ND & NA & ND & ND & ND & NA & NA & $x$ \\
\hline Oligohydramnios and anhydramnios & ND & ND & ND & ND & ND & ND & $x$ & ND & NA & NA & ND \\
\hline $\begin{array}{l}\text { Abnormal arterial flow in the cerebral or umbilical } \\
\text { arteries }\end{array}$ & ND & ND & ND & ND & ND & ND & $x$ & ND & NA & NA & ND \\
\hline Intrauterine growth restriction & ND & ND & ND & ND & ND & ND & $x$ & ND & NA & NA & ND \\
\hline Elective termination of pregnancy & NA & NA & NA & $\mathrm{X}$ & $x$ & NA & NA & NA & NA & NA & NA \\
\hline
\end{tabular}

Source: Prepared by the authors from information in items included in this article's References listing and in other sources: A: (8); B: (9); C: Jouannic JM, Friszer S, Leparc ND, Goffart I, et al. Zika virus infection in French Polynesia. Lancet. 2016 Mar 12;387(10023):1051-2.; D: Mlakar J, Korva M, Tul N, Popović M, Poljšak-Prijatelj M, Mraz J, et al. Zika virus associated with microcephaly. N Engl J Med. 2016 Mar 10;374(10):951-8.; E: Driggers RW, Ho CY, Korhonen EM, Kuivanen S, Jääskeläinen AJ, Smura T, et al. Zika virus infection with prolonged maternal viremia and fetal brain abnormalities. N Engl J Med. 2016 Jun 2;374(22):2142-51;; F: Oliveira Melo AS, Malinger G, Ximenes R, Szejnfeld PO, Alves Sampaio S, Bispo de Filippis AM. Zika virus intrauterine infection causes fetal brain abnormality and microcephaly: tip of the iceberg? Ultrasound Obstet Gynecol. 2016 Jan;47(1):6-7.; G: (13); H: Martines RB, Bhatnagar J, Keating MK, et al. Notes from the field: evidence of Zika virus infection in brain and placental tissues from two congenitally infected newborns and two fetal losses Brazil. MMWR Morb Mortal Wkly Rep 2016;65:159-60.; I: Cavalheiro S, Lopez A, Serra S, Da Cunha A, da Costa MD, Moron A, et al. Microcephaly and Zika virus: neonatal neuroradiological aspects. Childs Nerv Syst. 2016 Jun;32(6):1057-60.; J: de Fatima Vasco Aragao M, van der Linden V, Brainer-Lima AM, Coeli RR, Rocha MA, Sobral da Silva P, et al. Clinical features and neuroimaging (CT and MRI) findings in presumed Zika virus related congenital infection and microcephaly: retrospective case series study. BMJ. 2016 Apr 13;353:11901.; K: van der Linden V, Pessoa A, Dobyns W, Barkovich AJ, Júnior HV, Filho EL. Description of 13 infants born during October 2015-January 2016 with congenital Zika virus infection without microcephaly at birth - Brazil. MMWR Morb Mortal Wkly Rep. 2016 Dec 2;65(47):1343-8.

a $N D=$ not described.

${ }^{\mathrm{b}} \mathrm{NA}=$ not applicable.

It is important to note that in 2010 the 63rd World Health Assembly adopted a resolution urging countries to develop systems and to train staff in relation to the prevention of congenital anomalies, as well as to strengthen surveillance systems (16). The resolution also called on countries to provide appropriate health care for people with congenital anomalies and for their families. This step has been neglected in public agendas, despite the efforts of nongovernmental organizations, health professionals, and health authorities.

Beginning with the microcephaly outbreak in Brazil (6), and in accordance with WHO recommendations, several countries in the Americas began to implement actions focused on detecting ZIKV infections and microcephaly and other congenital anomalies. These actions by the ministries of health have mainly included training health professionals and developing and strengthening guidelines and registers. Another challenge has been to integrate different health functions that are generally conducted by separate departments in the health system, such as surveillance, prevention, and assistance related to Zika virus infections and the occurrence of microcephaly. The example of Brazil is illustrative: meetings and discussions led to production of a publication on integrated protocols for facing Zika virus infections, including surveillance and management of care for pregnancies and for affected infants (the latest version of this document is available at: http://portalarquivos.saude.gov.br/images/pdf/ 2016 / dezembro/12/orientacoes-integradasvigilancia-atencao.pdf).

\section{PUBLIC HEALTH IMPORTANCE AND ACTION}

The ZIKV outbreak in the Americas began in Brazil and has spread throughout the Region of the Americas. In contrast to other infections caused by arboviruses transmitted by the same vector (A. aegypti), such as dengue, chikungunya, and yellow fever (which can be fatal), 


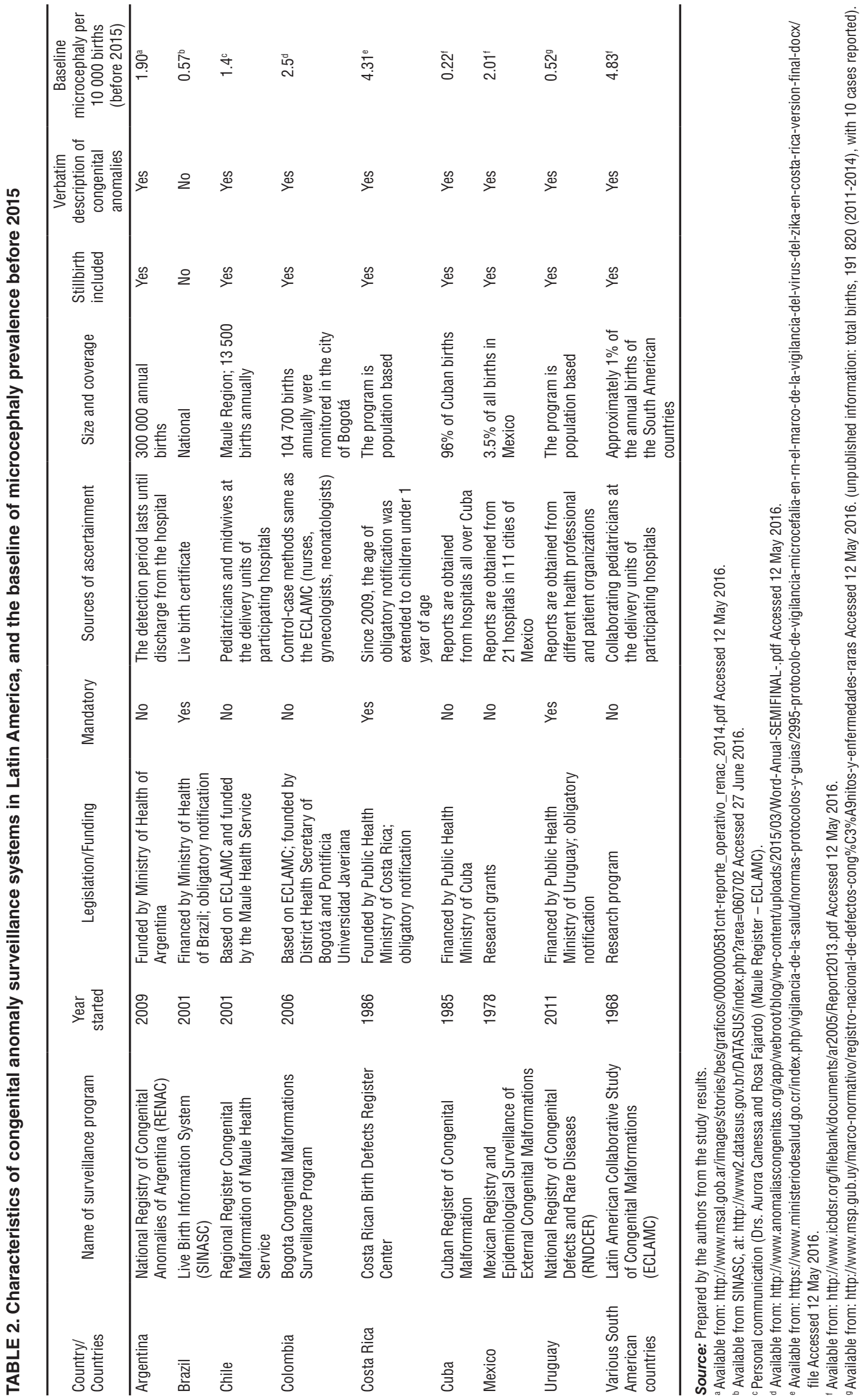


ZIKV has mild symptoms in the affected person but has a devastating teratogenic potential $(17,18)$. This situation is quite critical for families, as well as a challenge for health systems. The technology available has already enabled recognition of the genomic sequence of ZIKV, which may help explain the epidemiological findings and the neurotropism. The surveillance systems for communicable diseases are on maximum alert, and various government actions at the regional level have been taken in an attempt to reverse the current lack of data, improve information, and develop a common strategic plan to control the epidemic.

With ZIKV, there is no safe period in pregnancy, and babies can be adversely affected in all pregnancy trimesters (13). Therefore, the WHO has issued recommendations about monitoring infection by ZIKV and its consequences, including actions for surveillance and notification of cases of microcephaly and GBS. These recommendations differ according to a country's situation: a) with epidemic transmission of ZIKV; b) with possible endemic transmission of the virus; c) at risk of transmission of the virus; and d) with no risk or low risk of transmission of ZIKV by vector mosquitoes.

In general, in line with recommendation that the WHO has made to member states, some of the indicators that should be reported are: 1) number of ZIKV cases; 2) number of ZIKV deaths; 3) number of GBS cases and deaths; 4) number of microcephaly cases; 5) number of other anomalies; 6) number of countries with autochthonous transmission; and 7) number of newly affected countries.

In addition, cases of microcephaly should continue to be monitored, accuracy of OFHC measurement in newborns should be improved, and appropriate internationally established growth curves (such as those of the INTERGROWTH-21st Consortium (19)) should be used. Finally, in countries where the epidemic is already present, it is important to have a more sensitive but less specific tool to detect brain abnormalities, such as defining microcephaly to include head circumference less than $2 z$-scores below the mean.

Nevertheless, this more inclusive definition of microcephaly cannot be generalized. In Brazil, for example, with 3000000 births per year, a less strict definition of microcephaly (head circumference of $33 \mathrm{~cm}$ or less) led to a significant number of healthy babies being included in routine exam protocols. The health system almost collapsed due to thousands of babies being referred for clinical and laboratory protocols. Therefore, both the risks and the benefits of different criteria for inclusion of suspected cases of brain anomalies should be assessed separately for each country and each scenario. A good discussion of different diagnostic criteria for suspected microcephaly is given by Victora et al. (19).

In the countries where Zika virus infection is spreading, other congenital infections, such as syphilis, cytomegalovirus, and toxoplasmosis, are also prevalent, but rarely diagnosed early. Microcephaly can also be secondary to prenatal alcohol consumption, which is also not diagnosed in the neonatal period. Therefore, surveillance systems that are sensitive to microcephaly will have the benefit of also diagnosing other preventable cases of this congenital defect. The focus should be on prevention, early detection, and management of cases and evaluation of health needs to help prioritize actions. Currently, there are cohorts of infants and pregnant women who are being followed very closely by the health systems of different countries in the Americas. This active search for congenital anomalies will uncover many more cases of microcephaly and other abnormalities that would otherwise be missed. Upon being detected by the health system, the babies and their families should be able to count on specific early diagnosis, in line with the Convention on the Rights of Persons with Disabilities (20).

The Latin American Network of Congenital Malformations (ECLAMC) is taking the first steps to form a regional surveillance network that aims to: a) disseminate, via a Web page, the base frequencies of congenital anomalies at birth and b) provide statistical programs that any person or ministry of health can use to analyze temporal (epidemic) or geographical (endemic) frequencies (12). In response to the WHO resolution on birth defects (16), another initiative involves specific courses directed to Latin American countries on surveillance of birth defects and prematurity (see, for example: http://www.paho.org/clap/index. php?option $=$ com_content $\&$ view $=$ article $\& i d=421$ : comprometidos-en-la-prevencion-y-vigilancia-deanomalias-congenitas-y-partos-prematuros\&Itemid= $354 \&$ lang $=$ en).

It is important to ensure that all these activities help develop local efforts that work toward recognizing congenital anomalies and their causes, as well as training experts in disabilities and rehabilitation. One instrument that might help low- and middle-income countries in these endeavors is the Health Needs Assessment Toolkit for Congenital Disorders, which was developed by the PHG Foundation and is freely available (http:/ / www.bornhealthy.org/toolkit.html).

\section{CONCLUSIONS}

Seldom has there been in the scientific literature such vast production in record time as has occurred with the congenital ZIKV infections and the microcephaly outbreak in Brazil. From the detection of cases of embryopathy by ZIKV, it is possible to delve into the etiology of microcephaly and other congenital anomalies. The neurological findings described initially may be the tip of the iceberg. We consider this to be a unique opportunity to develop, strengthen, and improve the surveillance systems for congenital anomalies, as well as teratogen information services, in the Region of the Americas. This will help develop knowledge on potential new and emerging teratogenic agents, and help establish networks to monitor indicators of progress in each country.

WHO has started coordinating efforts to define the congenital Zika virus syndrome and has issued an 
open invitation to all partners to join in this effort (21). Creating health needs assessment tools for low- and middle-income countries may help to develop effective policies to ensure primary, secondary, and tertiary prevention measures for congenital anomalies. In addition, until a ZIKV vaccine is available, an informed society is the best ally in effectively acting on vector control and protecting individuals. Also critical is an intersectoral policy related to housing, sanitation systems (especially for quality water supply and garbage collection), and health care. These kinds of initiatives will be useful for ZIKV congenital syndrome control, and they can also have a much wider impact on a significant proportion of preventable and manageable congenital conditions.
Acknowledgments. The authors are grateful for technical help from Dr. Diana Valencia, of the Pregnancy and Birth Defects Team, Zika Virus Response Team, U.S. Centers for Disease Control and Prevention.

Funding. Dr. Larrandaburu holds a Ph.D. scholarship from CAPES (Brazilian Ministry of Education).

Conflicts of Interest. None declared.

Disclaimer. Authors hold sole responsibility for the views expressed in the manuscript, which may not necessarily reflect the opinion or policy of the RPSP/ PAJPH or PAHO.

\section{REFERENCES}

1. World Health Organization. WHO statement on the first meeting of the International Health Regulations (2005) (IHR 2005) Emergency Committee on Zika virus and observed increase in neurological disorders and neonatal malformations. Available from: http://www.who.int/mediacentre/news/statements/2016/1stemergency-committee-zika/en/ Accessed 5 February 2016.

2. Samarasekera U, Triunfol M. Concern over Zika virus grips the world. Lancet. 2016 Feb 6;387(10018): 521-4. Doi: 10.1016/S0140-6736(16) 00257-9.

3. Zanluca C, Melo VC, Mosimann AL, Santos GI, Santos CN, Luz K. First report of autochthonous transmission of Zika virus in Brazil. Mem Inst Oswaldo Cruz. 2015 Jun;110(4): 569-72. doi: 10.1590/0074-0276 0150192.

4. Pan American Health Organization/ World Health Organization. Zika Epidemiological Update 17 November 2016. Washington, D.C.: PAHO/ WHO; 2016.

5. Chouin-Carneiro T, Vega-Rua A, Vazeille M, Yebakima A, Girod R, Goindin D, Dupont-Rouzeyrol M, et al. Differential susceptibilities of Aedes aegypti and Aedes albopictus from the Americas to Zika virus. PLoS Negl Trop Dis. 2016 Mar 3;10(3): e0004543. doi: 10.1371/journal.pntd. 0004543.

6. Brasil, Ministério da Saúde. Microcefalia - boletim epidemiológico [Internet]. Brasília: Ministério da Saúde; 2015. Available from: http:/ / portalsaude.saude.gov.br/ index.php/cidadao/principal/ agencia-saude/20805-ministerioda-saudedivulga-boletim-epidemiologico Accessed 17 November 2015.

7. Campos GS, Bandeira AC, Sardi SI. Zika virus outbreak, Bahia, Brazil.
Emerg Infect Dis. 2015 Oct;21(10): 1885-6.

8. Schuler-Faccini L, Ribeiro EM, Feitosa IM, Horovitz DD, Cavalcanti DP, Pessoa A, et al. Possible association between Zika virus infection and microcephaly-Brazil, 2015. MMWR Morb Mortal Wkly Rep. 2016 Jan 29;65(3):59-62. doi: 10.15585/mmwr.mm6503e2.

9. Ventura CV, Maia M, Bravo-Filho V, Góis AL, Belfort R Jr. Zika virus in Brazil and macular atrophy in a child with microcephaly. Lancet. 2016 Jan 16;387(10015):228. doi: 10.1016/S0140-6736(16)00006-4. Epub 2016 Jan 8.

10. Brasil, Ministério da Saúde, Centro de Operações de Emergências em Saúde Pública sobre Microcefalias. Informe epidemiológico 53-semana epidemiológica 46/2016 (13/11 a 19/11/2016). Monitoramento de Casos de Microcefalia no Brasil. Brasília: Ministério da Saúde, 2016. Available from: http:// combateaedes.saude.gov.br/images/ boletins-epidemiologicos/informe_ microcefalia_epidemiologico53.pdf Accessed 30 November 2016.

11. França GV, Schuler-Faccini L, Wanderson K, Oliveira WK, Henriques $\mathrm{CM}$, Carmo HE, et al. Congenital Zika virus syndrome in Brazil: a case series of the first 1501 livebirths with complete investigation. Lancet. 2016 Aug 27;388(10047):891-7. doi: 10.1016/S0140-6736(16)30902-3. Epub 2016 Jun 29.

12. Estudio Colaborativo Latino Americano de Malformaciones Congénitas. Documento ECLAMC Final V3. Available from: http://www. eclamc.org/descargas/6.DocumentoECLAMCFinalV3.docx Accessed 17 February 2017.

13. Brasil P, Pereira JP Jr, Moreira ME, Ribeiro Nogueira RM, Damasceno L, Wakimoto M, et al. Zika virus infection in pregnant women in Rio de
Janeiro. N Engl J Med. 2016 Dec 15;375(24):2321-2334. Epub 2016 Mar 4.

14. World Health Organization. Zika situation report 24 November 2016: Zika virus, microcephaly and Guillain-Barré syndrome. Geneva: WHO; 2016. Available from: http:// www.who.int / emergencies / zika-virus / situation-report/24november-2016/en/ Accessed 30 November 2016.

15. Hills SL, Russell K, Hennessey M, Williams C, Oster AM, Fischer M, et al. Transmission of Zika virus through sexual contact with travelers to areas of ongoing transmission - continental United States, 2016. MMWR Morb Mortal Wkly Rep. 2016 Mar 4;65(8):215-6. doi: 10.15585/mmwr. $\mathrm{mm} 6508 \mathrm{e} 2$.

16. World Health Organization. Birth defects. (Sixty-Third World Health Assembly WHA63.17). Available from: http://apps.who.int/ $\mathrm{gb} /$ ebwha/pdf_files/WHA63/ A63_R17-en.pdf Accessed 26 June 2016.

17. Schuler-Faccini L, Sanseverino MT, Vianna FS, da Silva AA, Larrandaburu M, Pereira CM, et al. Zika virus: a new human teratogen? Implications for women of reproductive age. Clin Pharmacol Ther. 2016 Apr 18. doi: 10.1002/cpt.386. [Epub ahead of print] PubMed PMID: 27090438.

18. Rasmussen, SA, Jamieson, DJ, Honein MA, Petersen LR. Zika virus and birth defects--reviewing the evidence for causality. N Engl J Med. 2016 May 19;374(20):1981-7. doi: 10.1056/NEJMsr1604338. Epub 2016 Apr 13.

19. Victora CG, Schuler-Faccini L, Matijasevich A, Ribeiro E, Pessoa A, Barros FC. Microcephaly in Brazil: how to interpret reported numbers? Lancet. 2016 Feb 13;387(10019): 
621-4. doi: 10.1016/S0140-6736(16)00 273-7. Epub 2016 Feb 7.

20. United Nations. Convention on the Rights of Persons with Disabilities (CRPD). New York: UN; 2016. Available from: https://www.un.org/ development/desa/disabilities/ convention-on-the-rights-of- persons-with-disabilities.html Accessed 26 June 2016.

21. Costello A, Dua T, Duran P, Gülmezoglu M, Oladapo TO, Perea $\mathrm{W}$, et al. Defining the syndrome associated with congenital Zika virus infection. Bull World Health Organ.
2016 Jun 1;94(6):406-406A. doi: 10.2471/BLT.16.176990.

Manuscript received on 27 December 2016. Revised version accepted for publication on 14 August 2017.
RESUMEN

La infección por el virus del Zika y las anomalías congénitas en la Región de las Américas: oportunidades para la acción regional

Palabras clave
El virus del Zika (ZIKV) se identificó en 1947 en el bosque de Zika, en Uganda, pero recientemente ha surgido como una amenaza para la salud pública. Los primeros datos de la infección en seres humanos surgieron en 1952, pero no fue hasta abril del 2007 que se reconoció el primer brote en seres humanos. En la Región de las Américas, en el 2015 se inició un brote del virus en el Brasil, y desde la segunda mitad de ese año en adelante se empezó a notificar a las autoridades de salud un número considerable de recién nacidos con microcefalia grave. En febrero del 2016, la Organización Mundial de la Salud (OMS) declaró que los conglomerados de casos de microcefalia detectadas en las zonas afectadas por el ZIKV constituían una emergencia de salud pública de importancia internacional. Raramente ha habido una consiguiente producción tan vasta de publicaciones científicas en un tiempo récord. En este informe se aborda la repercusión de la infección por el ZIKV durante el embarazo, el diagnóstico y la vigilancia de la microcefalia, el reconocimiento de un fenotipo clínico de la infección congénita por el ZIKV y las oportunidades para las intervenciones de salud pública. Consideramos que se trata de una oportunidad única para los países de la Región de las Américas de desarrollar, fortalecer y mejorar los sistemas de vigilancia de las anomalías congénitas y los servicios de información sobre teratógenos. La creación de herramientas de evaluación de las necesidades de salud para los países de ingresos bajos y medianos puede ayudarles a elaborar políticas eficaces destinadas a asegurar medidas preventivas primarias, secundarias y terciarias para las anomalías congénitas. Dichas iniciativas serán útiles para el control del síndrome congénito del ZIKV y también para tener una incidencia mucho mayor sobre una proporción significativa de las enfermedades congénitas prevenibles y controlables.

Virus Zika; microcefalia; vigilancia epidemiológica; Américas.
RESUMO

\section{Infecção pelo vírus Zika e malformações congênitas nas Américas: oportunidades para ação regional}

O vírus Zika (ZIKV) foi identificado em 1947 em animais na floresta de Zika, em Uganda, mas se tornou um grande risco à saúde pública nos últimos anos. A primeira evidência de infecção humana data de 1952, porém o primeiro surto em seres humanos foi registrado somente em abril de 2007. Na Região das Américas, o Brasil registrou um surto de zika em 2015 e, a partir de meados daquele ano, passou a ser notificado aos órgãos de saúde um número considerável de casos de recém-nascidos com microcefalia grave. Em fevereiro de 2016, a Organização Mundial da Saúde (OMS) decretou que a concentração de casos de microcefalia nas áreas de ocorrência de zika representava uma situação de emergência em saúde pública de interesse internacional. Raras vezes se viu tamanha produção de conhecimento científico em tão pouco tempo. Este artigo examina as consequências da infecção pelo vírus Zika durante a gestação, discorre sobre o diagnóstico e a vigilância de casos de microcefalia e a identificação de um fenótipo clínico da infecção congênita pelo ZIKVS e aponta oportunidades 
para ação em saúde pública. Os autores consideram ser esta uma oportunidade única aos países da Região das Américas de expandir a capacidade e reforçar e melhorar a qualidade dos sistemas de vigilância de malformações congênitas e os serviços de informação sobre teratogenicidade. Desenvolver instrumentos para avaliar as necessidades em saúde dos países de baixa e média renda pode favorecer a formulação de políticas eficazes que garantam medidas de prevenção primária, secundária e terciária de malformações congênitas. Tais iniciativas possibilitariam o controle da síndrome congênita do zika e também poderiam repercutir mais amplamente em um conjunto importante de afecções congênitas que podem ser prevenidas e controladas.

Palavras-chave Zika virus; microcefalia; vigilância epidemiológica; Américas. 